\title{
Prevalence of hock, knee, and neck skin lesions and associated risk factors in dairy herds in the Maritime Provinces of Canada
}

\author{
M. T. Jewell, ${ }^{1 *}$ M. Cameron, ${ }^{1}$ J. Spears, ${ }^{2}$ S. L. McKenna, ${ }^{1}$ M. S. Cockram, ${ }^{1}$ J. Sanchez, ${ }^{1}$ and G. P. Keefe ${ }^{1}$ \\ ${ }^{1}$ Department of Health Management, Atlantic Veterinary College, University of Prince Edward Island, Charlottetown, Prince Edward Island, \\ Canada, C1A 4P3 \\ ${ }^{2}$ Department of Biomedical Sciences, Atlantic Veterinary College, University of Prince Edward Island, Charlottetown, Prince Edward Island, \\ Canada, C1A 4P3
}

\section{ABSTRACT}

Skin lesions are commonly seen in dairy herds and have been associated with animal-, environmental-, and management factors. These lesions are not only a welfare concern, but they also affect profitability. Three areas on the cattle were examined for skin lesions: the hock, knee, and neck. Previous Canadian studies estimating the prevalence of lesions and the risk factors associated with them have not included the Maritime Provinces. In this study, 73 herds in the Maritime Provinces were chosen voluntarily to participate, with both tiestalls (n $=33)$ and freestalls $(\mathrm{n}=40)$ represented. Within each herd, 67 to $90 \%$ of the lactating cows were selected and assessed for potential animal-, environmental-, and management-based risk factors. If producers were aware of the potential risk factors, this could help them reduce the prevalence in their herd. Leg lesions were scored on a 4-point scale (0-3) based on hair loss, swelling, and scabs, with a lesion defined as a score of 2 or 3 on at least 1 hock or knee. Necks were scored on a 3 -point scale (0-2), with a lesion defined as score 2 . For freestalls, the prevalence (95\% confidence interval) of hock lesions was 39\% (29-49\%), knee lesions was $14 \%$ (11-18\%), and neck lesions was 1\% (<1-2\%). Similarly, for tiestalls the prevalence (95\% confidence interval) of hock lesions was 39\% (33-46\%), knee lesions was $17 \%(13-22 \%)$, and neck lesions was 5\% (3-8\%). Due to differences in management and methods of assessment between facility types, tiestalls and freestalls were analyzed separately. Due to dichotomization of cows as having a skin lesion or not, random-effects multivariable logistic regression was used to determine the risk factors for each lesion and facility type. Several environmental-based measurements, such as the stall base, type and dryness of bedding, and type of milking

Received May 17, 2018.

Accepted December 6, 2018.

*Corresponding author: mtjewell@upei.ca parlor, were associated with leg lesions. An environmental-based measurement that was associated with neck lesions was the design of the feed rail barrier in freestalls and the dimensions of the tie rail in tiestalls. Animal-based risk factors, such as stage of lactation, parity, and body condition, were also associated with all 3 types of lesions. This study showed that lesions to the hock, knee, and neck were common in the Maritime Provinces of Canada. Although differences were seen between facility types, in general, the results suggest that improving stall design and management and feed bunk design would help producers reduce the number of skin lesions seen in dairy cattle.

Key words: dairy welfare, freestall, tiestall, skin lesion

\section{INTRODUCTION}

Skin lesions of the hock, knee, and neck are common problems seen in commercial dairy operations. These types of lesions, even when mild, show inflammatory changes when assessed with histology and thermography, and this suggests that they might cause pain or discomfort (Haager, 2016). Over the past decade, the global prevalence of lesions to the hock joints of dairy cattle has been reported to be 40 to $81 \%$ (Kielland et al., 2009; von Keyserlingk et al., 2012; Chapinal et al., 2014; Zaffino Heyerhoff et al., 2014). Studies conducted in North America reported that between 1 and $43 \%$ of cows had knee lesions (von Keyserlingk et al., 2012; Zaffino Heyerhoff et al., 2014; Nash et al., 2016). Although not as often studied as leg lesions, neck lesions are also of interest in terms of dairy welfare. Two Canadian studies found a prevalence of neck lesions of $4 \%$ in tiestall facilities (Zurbrigg et al., 2005a) and 9\% in freestall facilities (Zaffino Heyerhoff et al., 2014). The overall prevalence of hock and knee lesions reported in these studies was quite high; however, within individual herds the prevalence of these lesions can be very low to none (von Keyserlingk et al., 2012; Zaffino Heyerhoff et al., 2014; Nash et al., 2016), demonstrating that reducing lesions is an achievable goal for producers. 
Skin lesions to the legs of dairy cows have been associated with environmental-based measures, such as dimensions of the stalls (Zurbrigg et al., 2005b; Keil et al., 2006; Zaffino Heyerhoff et al., 2014; Nash et al., 2016), type and amount of bedding provided (Kielland et al., 2009; Potterton et al., 2011), and type of material used for the base of the stall (Weary and Taszkun, 2000; Andreasen and Forkman, 2012; Zaffino Heyerhoff et al., 2014; Nash et al., 2016), making them an indicator of how well the animal is interacting with their physical environment. Animal-based measures that have been associated with leg lesions include body condition (Kielland et al., 2009; Nash et al., 2016), cleanliness of the cow (Potterton et al., 2011), the stage of production (Kielland et al., 2009; Zaffino Heyerhoff et al., 2014; Nash et al., 2016), and parity (Kielland et al., 2009; Potterton et al., 2011; Zaffino Heyerhoff et al., 2014; Nash et al., 2016).

Previous studies have found that hock lesions are associated with lameness (Potterton et al., 2011; Zaffino Heyerhoff et al., 2014). Although the causal relationship between the two is unclear, severe lameness can be seen when hock lesions are accompanied by severe swelling or infection. Hock lesions can lead to the development of arthritis and hygromas, which can limit the range of motion in the joint and cause pain (Kester et al., 2014). Hock lesions have also been associated with risks of reduced health and productivity, such as increased SCC and higher culling rates (Fulwider et al., 2007).

Although the direct cost of hock lesions is unclear, their presence can have an economic impact on the industry. Due to their association with lameness, one of the most costly health concerns in the dairy industry (Dolecheck and Bewley, 2018), hock lesions would be expected to contribute to these losses (Kester et al., 2014). It is important that producers are aware of the prevalence of lesions in their herd and what areas of management could be modified to improve the welfare of their animals and increase the profitability of their farm.

There is currently little information about the prevalence of lesions on dairy farms in the Maritime region of Canada. The goals of the current study were to establish the prevalence of skin lesions to hocks, knees, and necks on dairy cattle in the Maritime Provinces of Canada and to determine associated animal-, environmental-, and management-based risk factors.

\section{MATERIALS AND METHODS}

\section{Herd Selection}

Of a possible 588 farms available for participation from New Brunswick, Nova Scotia, and Prince Edward
Island, Canada (CDIC, 2016), 80 herds (13.6\%) were chosen voluntarily for this study. To reflect the population of herds, we aimed to have the participation of approximately $50 \%$ tiestall herds and $50 \%$ freestall herds (CDIC, 2016). Herds were eligible for inclusion in the study if they were enrolled in the regional milk recording service provided by Valacta Inc. (SainteAnne-de-Bellevue, Quebec, Canada) and were milking primarily (>80\%) Holstein cows. Enrollment of herds was based on voluntary interest in the study through advertisements in provincial dairy board newsletters, Valacta Inc. seminars on cow comfort, and recruitment by regional veterinarians.

\section{Cow Selection}

The number of cows assessed from each herd or management group within a herd (freestall facilities) was determined using a sample size calculation for proportions based on the herd or group size, an estimated prevalence of $10 \%$, a precision of $5 \%$, and an accuracy of $95 \%$. When assessing freestall herds with multiple groups of lactating cows, the number of cows to be assessed was calculated based on the size of each group separately when groups were (1) not in contact with one another (e.g., separated by the feed alley) or (2) had distinctly different designs (e.g., flooring type, stall base, or feed bunk rails). This would allow for the comparison of different design features within herds. However, this meant that more cows would be assessed per herd. To help decrease the time spent on-farm to perform the assessment, if management groups were in contact with one another (e.g., separated by a gate) and had similar design features, the number of cows to assess was calculated based on the total size of both groups. Cows were chosen proportionately from each group.

In tiestalls, cows were selected for the assessment using a systematic random sampling scheme. However, in freestall herds, a random sampling scheme was not as easily achievable due to the assessment being completed while the cows were freely moving around. To compensate for this, the observers took care to select animals from different areas of the pen and animals performing different behaviors, such as lying, feeding, walking, and drinking, and not just those in the proximity of the observers. Animals were selected as the observers walked through the herd until the required number of animals had been assessed. Due to the large proportion of the herd being sampled (67-90\%), achieving this required multiple trips around the entire pen. Cows were uniquely identified to ensure that they were not scored multiple times throughout the process. When locking head gates were present at the feed bunk or assessment 
Table 1. Description of the scoring system used to assess hock, knee, and neck lesions based on Gibbons et al. (2012)

\begin{tabular}{lll}
\hline & & \multicolumn{2}{c}{ Description } \\
\cline { 2 - 3 } Score & Hock and knee & Neck \\
\hline No lesion & & \\
0 & No swelling, no missing hair; some broken hairs present & No swelling, no missing hair; some broken hairs present \\
1 & Bald area or minor swelling $(<1 \mathrm{~cm})$ & No swelling, bald area \\
Lesion & Moderate swelling $(<2.5 \mathrm{~cm})$ or break in skin or scab present & Swelling or break in skin or scab present \\
2 & Major swelling $(\geq 2.5 \mathrm{~cm}) ;$ may have bald area or break in skin & Not applicable \\
3 & &
\end{tabular}

had to be completed during milking, cows were selected using a systematic random sampling scheme similar to that used in tiestall facilities.

\section{On-Farm Assessment}

An assessment consisting of animal- and environmental-based measurements, as well as a management questionnaire as described below, was completed on-farm. Each on-farm assessment was completed by 2 assessors, one always being the first author (MJ) and the other a trained research assistant from the Atlantic Veterinary College (Charlottetown, PE, Canada). A total of 3 observers were trained between April 2015 and May 2016 and were required to achieve an acceptable level of interrater agreement $\left(\mathrm{K}_{\mathrm{w}}>0.6\right)$ to perform on-farm assessments. This level of agreement was achieved and maintained throughout the project. Assessments on the participating farms took place between September 2015 and July 2016. Tiestall herds that pastured their cattle were assessed in late spring, before the beginning of pasture season, to ensure that observations reflected the effects of the housing facility on the cows as much as possible. All methods used to collect the data were approved by the Animal Care Committee at the University of Prince Edward Island (Charlottetown, PE, Canada; protocol no. 15-015).

Cows selected within the study were assessed for skin lesions on the hock, knee, and neck using the scoring system described by Gibbons et al. (2012). Hock and knee lesions were scored on a 4-point scale and neck lesions were scored on a 3-point scale as described in Table 1. The BCS was assigned following the scoring chart developed by Vasseur et al. (2013) based on the Elanco Animal Health BCS for dairy cattle (Elanco Animal Health, 1996). Animals were assessed for cleanliness of leg, flank, and udder as described in Table 2. Leg cleanliness was evaluated on the lateral aspect of the right leg, focusing on the area between the lower half of the tarsal joint and the coronary band. Flank cleanliness was evaluated on the right side of the animal, focusing on the area from the upper half of the tarsal joint to the area between the hook and pin bones. Udder cleanliness was evaluated on the lower $50 \%$ of the udder, not including the teats (Vasseur et al., 2015). In tiestall herds, these assessments took place while the animals were in their stalls. In freestall herds, these assessments occurred in various locations within the pen, such as standing in a stall, at the feed bunk, and occasionally in the parlor. Regardless of the location, one observer was located behind the animal and the other was located in front of the animal to ensure that all areas were fully viewed.

Another measurement collected was the height of the cow at the rump and the width at the hook bones, as described by Nash et al. (2016). In tiestalls, this measurement was collected on all of the animals entered into the study and used to determine whether the dimensions of their stalls were appropriate for their size. In freestalls, because the cows do not have designated stalls, 6 of the larger animals were measured to determine whether the average stall size was appropriate for the larger animals in the group, following previously described recommendations (Vasseur et al., 2015).

Both qualitative and quantitative measurements of the environment were collected. The qualitative measurements taken during the assessment included amount, type, and dryness of bedding and floor cleanliness (at the feed bunk). The middle 2 stalls of each row were assessed for the quantity and quality of bedding as previously described (Solano et al., 2015; Nash et al., 2016). The quantity of bedding was subjectively

Table 2. Description of the scoring system used to assess cleanliness of the leg, flank, and udder based on Vasseur et al. (2015)

\begin{tabular}{ll}
\hline Score & Description \\
\hline Clean & Fresh manure splashes on $<50 \% 1$ of area \\
0 & Fresh manure splashes on $\geq 50 \%$ of area \\
1 & Dried manure on $\geq 50 \%$ of area \\
Dirty & Dried manure on entire area \\
2 & \\
3 &
\end{tabular}

${ }^{1} 50 \%$ of the area for the flank region was equivalent to standard lettersized paper for 1 single area of contamination. 
measured by visually assessing the amount of bedding covering the stall. This was assessed differently for different bedding types. For organic bedding material (e.g., straw, wood by-products), the quantity was considered to be deep if the layer of bedding was $>2 \mathrm{~cm}$ deep and little if the layer was $\leq 2 \mathrm{~cm}$ deep. For sand-bedded stalls, the quantity of bedding was considered deep if the sand was at the level of the rear curb or higher and little if the level of the sand was below the rear curb. The herd was considered to have deep bedding if $>50 \%$ of the assessed stalls were deep bedded. The dryness of the bedding was also measured in 2 separate areas in these same stalls. A piece of paper towel, folded in 4, was placed over the bedding sample, and the observer applied pressure to the sample with their knee for $3 \mathrm{~s}$. The quality of the bedding was determined to be dry, wet, or very wet based on the number of layers and size of the area that absorbed moisture on the paper towel, with the highest score being the final score for that stall (Vasseur et al., 2015). The cleanliness of the floor at the feed bunk was subjectively measured by walking up and down the area and assessing how much manure was present on the observer's boots at least 20 min after the area had been cleaned. The floor was considered clean if $\leq 1 \mathrm{~cm}$ of manure was collected on the boots and dirty if $>1 \mathrm{~cm}$ of manure was collected (Vasseur et al., 2015).

Quantitative measurements that were taken during the assessment included stall dimensions, height of feed bunk rail, and stocking density. The stall dimensions were assessed on the stalls at each end of each row and averaged across all stalls that were measured. The stall dimensions consisted of 9 aspects of stall design in freestalls and 4 aspects in tiestalls, as previously described (Zaffino Heyerhoff et al., 2014; Nash et al., 2016). The height of the feed bunk rail was measured in freestalls from the level of the floor on the cow side to the bottom edge of the railing or barrier if present. The stocking density was calculated as the number of cows in the group divided by useable stalls.

To collect information about the general management on each farm, a questionnaire was administered by interview on-farm. The questionnaire was adapted from Vasseur et al. (2015) with the addition of questions to gain information not measured during the assessment, such as "What is the estimated time to milk the entire herd?" "Do the lactating cows have access to pasture?" and "What type of facility are the dry cows kept in?" The questionnaire consisted of 61 multiple-choice and 54 short-answer questions for freestalls (Supplemental File S1; https://doi.org/10.3168/jds.2018-15080) and tiestalls (Supplemental File S2; https://doi.org/10 $.3168 /$ jds.2018-15080), respectively.

\section{Statistical Analysis}

All data were analyzed using Stata14 (StataCorp, College Station, TX). The experimental unit was the cow, with the outcome of interest being whether the cow had a skin lesion on their hock, knee, or neck; outcomes were dichotomized as a lesion or not based on the scoring system described in Table 1 . The prevalence, along with the $95 \%$ confidence interval, of lesions to the hock, knee, and neck were determined at the cow and herd levels, excluding herds that were not included in the risk factor analysis (see Results for the reasons for exclusion). The prevalence and 95\% confidence interval at the cow level were determined from the inverse logit of the null model to account for clustering within farms. Descriptive statistics (mean, standard deviation, minimum, and maximum) were used to review the characteristics of the outcome variables along with the cow- and herd-level explanatory variables. Explanatory variables for each outcome of interest were chosen based on the causal diagrams shown in Figures 1 and 2 , with intervening variables being excluded from the model building process (e.g., lameness for hock and knee lesions). The unconditional association between each explanatory variable and each outcome was tested using a random effect logistic regression model, with herd as the random effect, for both facility types. If an explanatory variable was unconditionally associated with the outcome of interest $(P<0.2)$, the variable was carried forward to the multivariable regression model. The linearity of continuous variables was assessed graphically on a logit scale as well as through the use of fractional polynomials (Dohoo et al., 2009). If the explanatory variable did not have a linear relationship with the outcome, it was transformed into a categorical variable using categories based on quartiles or industry recommendations and tested for its association with the outcome. The collinearity between the explanatory variables of interest was assessed, and if any variables were highly correlated $(\mathrm{r}>0.7)$ the most significant or biologically plausible was used for the multivariable analysis.

The final multivariable models were generated using a manual backward stepwise process starting with all variables of interest included in the model and eliminating the most nonsignificant $(P>0.05)$ variable one at a time and reconsidering previously removed variables. If the removal of a variable resulted in a $>30 \%$ change in coefficient of a remaining variable, it was considered to be a confounder and left in the model. Biologically plausible interaction variables were tested for the remaining significant variables and kept in the model if $P \leq 0.05$ for the interaction term. Finally, diagnostics 


\section{Stall Characteristics}

- Dimensions

- Stall Base

* Bedding Type/Depth

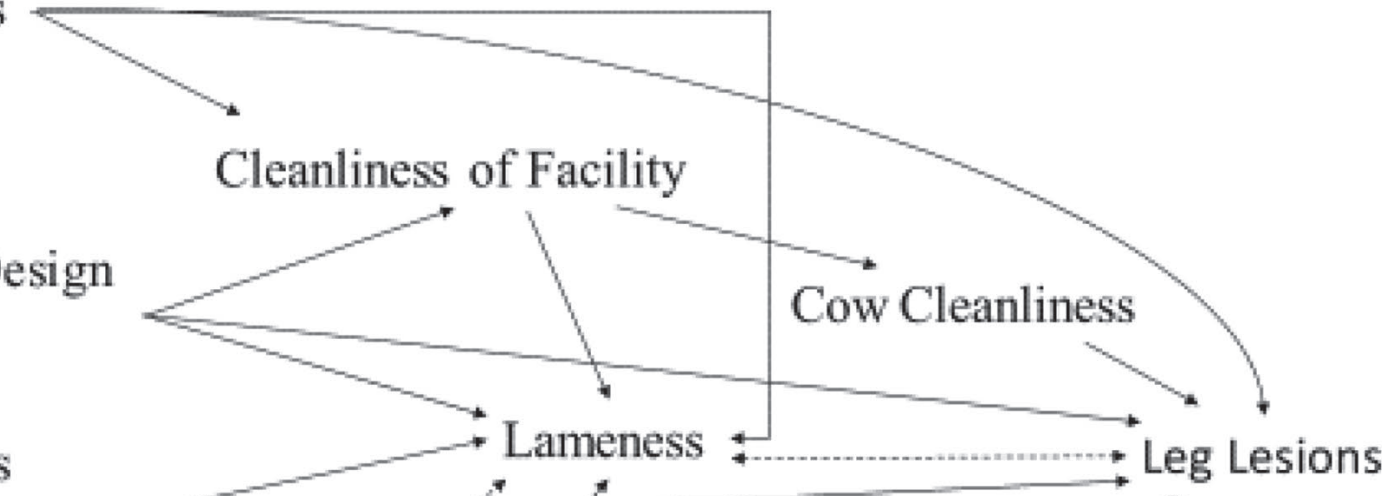

Cow Characteristics

- Parity

- DIM

- Size

\section{Feed Management}

- Ration Type

- Feeding Frequency/Push Up

\section{Other Management Factors}

\section{- Pasture Access}

\section{- Housing of Dry Cows/Heifers}

Figure 1. Causal diagram depicting the relationships considered between the animal-, environmental-, and management-based measurements and lesions to the hock and knee joints in tiestall and freestall facilities.

were performed on all models to assess the fit of the model. Residuals at the cow and herd levels were assessed for normality, visually with normality plots and statistically using a Shapiro-Wilk test.

The odds ratios of the risk factors of lesions to the hock, knee, and neck presented in this study are clusterspecific estimates; these estimates are used to make comparisons of the odds of skin lesions within one particular herd. This type of estimate was used to compare the odds of lesions within one herd for cow-level factors, such as parity or DIM, because variability in these predictors exists within each herd. However, with herdlevel predictors we wanted to compare cows in one herd with cows in another herd; therefore, cluster-specific estimates do not give us the most appropriate results. To correctly make comparisons between herds, a population-averaged estimate was used. These populationaveraged estimates can also be used for cow-level variables. The cow- and herd-level predictors are shown in Figures 3 and 4 . Estimates were converted from clusterspecific estimates to population-averaged estimates using the following relationship: $\beta_{\mathrm{k}} / \sqrt{ }\left(1+0.346 \times \sigma_{\text {herd }}^{2}\right)$, where $\beta_{\mathrm{k}}$ is the regression coefficient from predictor $\mathrm{k}$ from the random effects model (e.g., cluster-specific estimate) and $\sigma_{\text {herd }}^{2}$ is the herd-level variance. The herdlevel variance was determined using latent variables (Dohoo et al., 2009).

\section{RESULTS}

\section{Description of Study Population}

A total of 80 herds were assessed during the study, of which $46(58 \%)$ were housed in freestall facilities and 34 $(42 \%)$ were housed in tiestall facilities. The herds were distributed throughout the 3 Maritime Provinces of Canada, with 18 herds from New Brunswick, 32 herds from Nova Scotia, and 30 herds from Prince Edward Island. Within these herds, 1,523 tiestall cows and 3,129 freestall cows were assessed for skin lesions. Four freestall herds were excluded from the analysis due to inconsistencies in the availability of their production data provided by Valacta Inc. Two other freestall herds were excluded from the analysis due to their distinct 


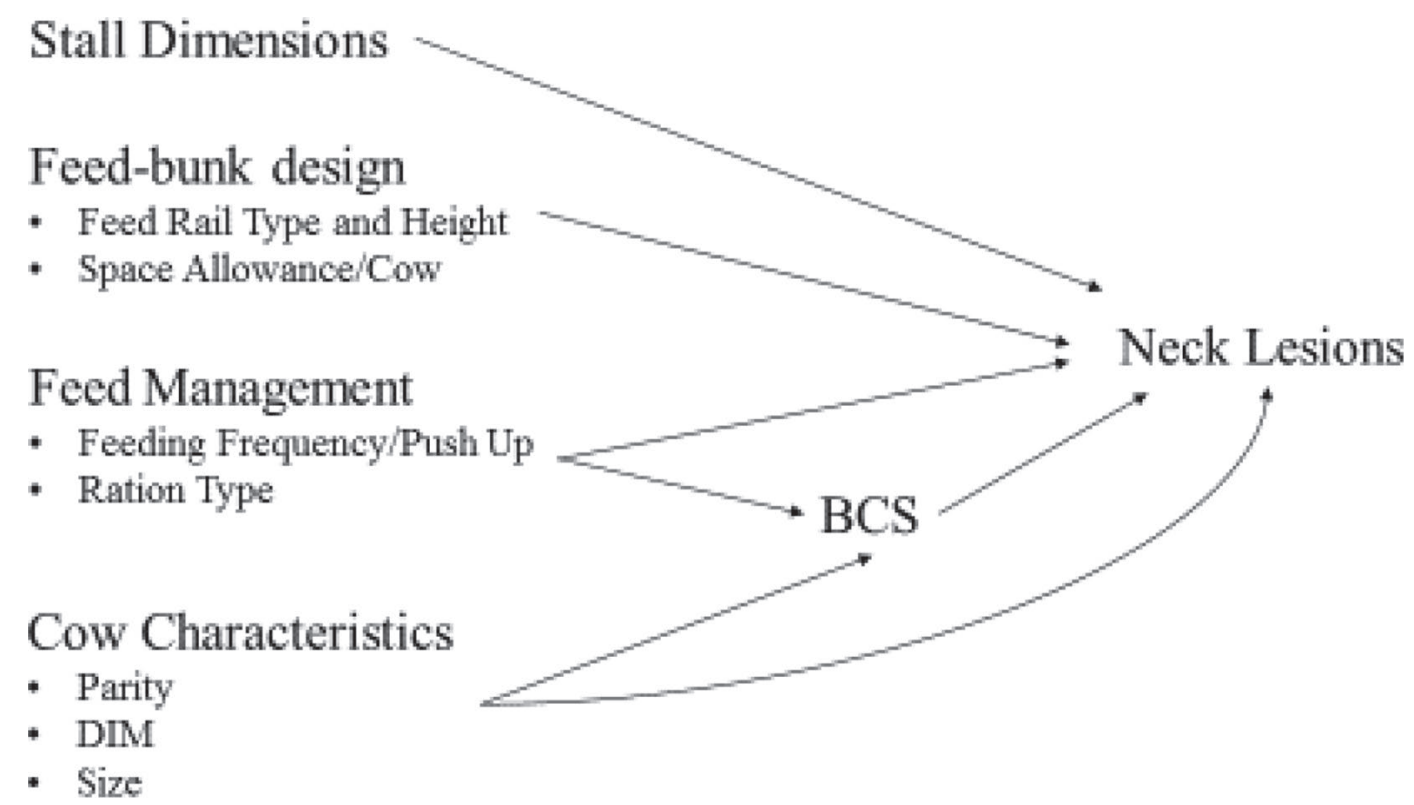

Figure 2. Causal diagram depicting the considered relationships between the animal-, environmental-, and management-based measurements and lesions to the neck in tiestall and freestall facilities.

differences in facility design and management: one was the only herd not providing bedding, and the other was the only facility with concrete-based stalls. One tiestall herd was excluded from the analysis due to its distinct difference in facility design, as it was the only facility with cows secured in their stall by means of stanchions, where 2 vertical bars enclosed the neck of the cow (Supplemental Tables S1-S5; https://doi.org/ 10.3168/jds.2018-15080).
The 33 tiestall herds included in the analysis ranged in size from 26 to 148 cows, with a median herd size (interquartile range) of $60(46-82)$ cows. These herds had an average (standard deviation) milk production of 9,538 (993) kg/cow per year. The 40 freestall herds included in the analysis ranged in size from 22 to 255 cows, with a median (interquartile range) of 90 (51-121) cows. These herds had an average (standard deviation) milk production of $10,112(1,214) \mathrm{kg} /$ cow per year.

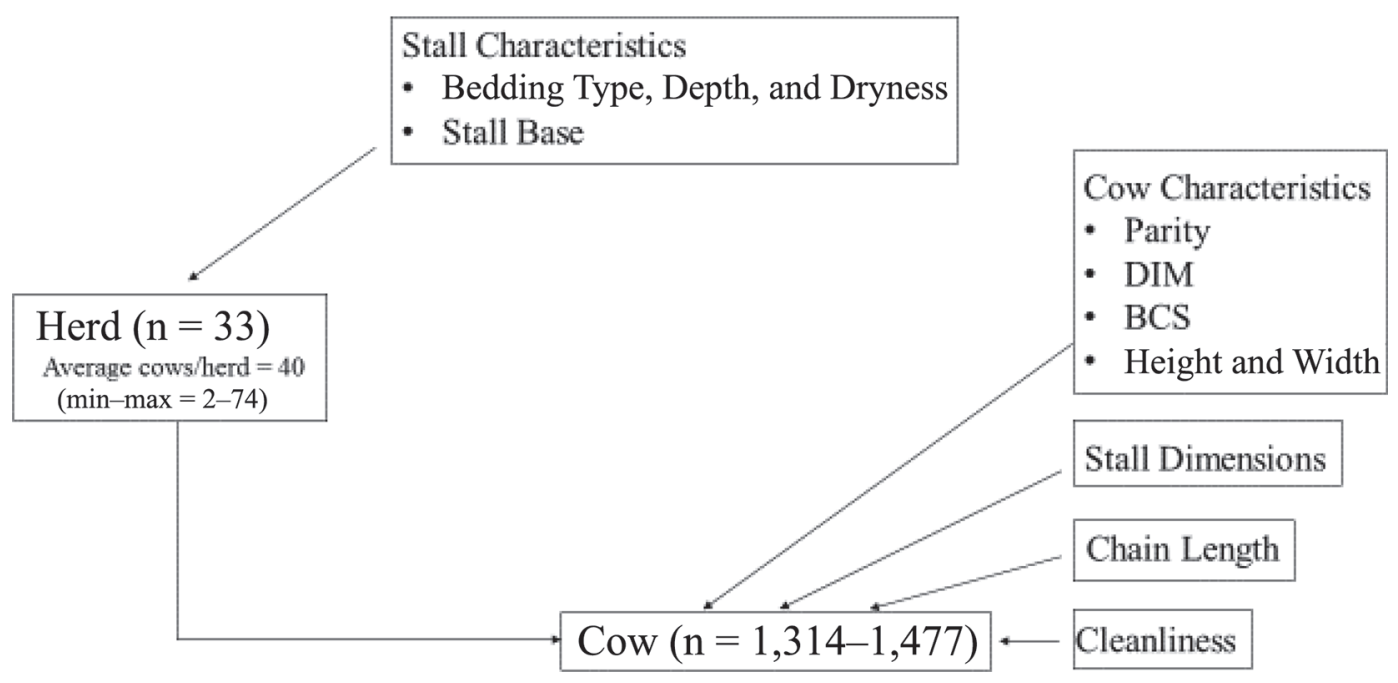

Figure 3. Hierarchical structure diagram illustrating the levels within the mixed-effect models for tiestall facilities as well as the risk factors associated with these levels. $\min =$ minimum; $\max =$ maximum. 
The facility design and management varied between herds. In the tiestall herds included in the analysis, 19 herds (58\%) used straw or hay as bedding, 7 herds (21\%) used a combination of straw and wood by-products (e.g., shavings, sawdust, or chipped construction waste), and 7 herds (21\%) used these wood by-products alone. For the purpose of the analysis, the latter 2 categories were combined as wood by-products and other. Under this bedding category, the most common stall base was geotextile mattresses, which were present in 16 herds $(48 \%)$. The other types of stall bases observed in the study population were rubber mats in 11 herds $(33 \%)$ and concrete in 6 herds $(18 \%)$.

In the freestall herds included in the final analysis, we found an average stocking density of $0.97(0.14)$ cows/stall. The height of the barrier present at the feed bunk was on average $133.5(12.0) \mathrm{cm} ; 1$ herd had no measurement because it used a tombstone-style feed barrier. Another factor of interest about these herds is the type of milking system present on the farm. The most common milking systems were herringbone (50\%) and parallel (23\%) parlors. Other parlor types included parabone and flat parlors (15\%). Automatic milking systems were present on 5 farms $(12 \%)$. Similar to the tiestall herds, the most common stall base present was geotextile mattresses, which were seen in $23(58 \%)$ of the freestall herds. Rubber mats were seen in $5(12 \%)$, and a soil base (defined as stalls with a sand or clay base) was seen in $12(30 \%)$. Looking at the material that was used to bed these stalls, wood by-products were used in $14(35 \%)$ of the herds, straw in $13(33 \%)$, and sand in $7(18 \%)$. Six (15\%) herds used chipped recycled construction waste, such as drywall and lumber, as bedding.

\section{Prevalence of Hock, Knee, and Neck Skin Lesions in Tiestalls}

The cow-level prevalence of hock lesions across the 33 tiestall herds was 39.3\% (95\% CI: 33.1-45.8), ranging from 11.7 to $75.0 \%$ within individual herds (Supplemental Figure S1; https://doi.org/10.3168/jds.2018 -15080). Of the 1,477 cows initially selected, 22 were excluded from the analysis because the hock joints were too dirty to score accurately. Of the remaining 1,455 cows with complete records for hock lesions, 47, 13, 39, and $1 \%$ had a maximum hock score of $0,1,2$, and 3 , respectively. The cow-level prevalence of knee lesions across all herds was $16.6 \%$ (95\% CI: 12.5-21.6), ranging from 2.2 to $78.2 \%$ within each herd (Supplemental Figure S2; https://doi.org/10.3168/jds.2018-15080). Of the 1,495 cows with records for knee lesions, 68, 13,18 , and $1 \%$ had a maximum knee score of $0,1,2$, and 3, respectively. The cow-level prevalence of neck lesions across all herds was 4.7\% (95\% CI: 2.7-7.9), with the prevalence ranging from 0 to $31.4 \%$ within herds (Supplemental Figure S3; https://doi.org/10 $.3168 /$ jds.2018-15080). Of the 1,500 cows with records for neck lesions, 87,5 , and $8 \%$ had scores of 0,1 , and 2 , respectively.

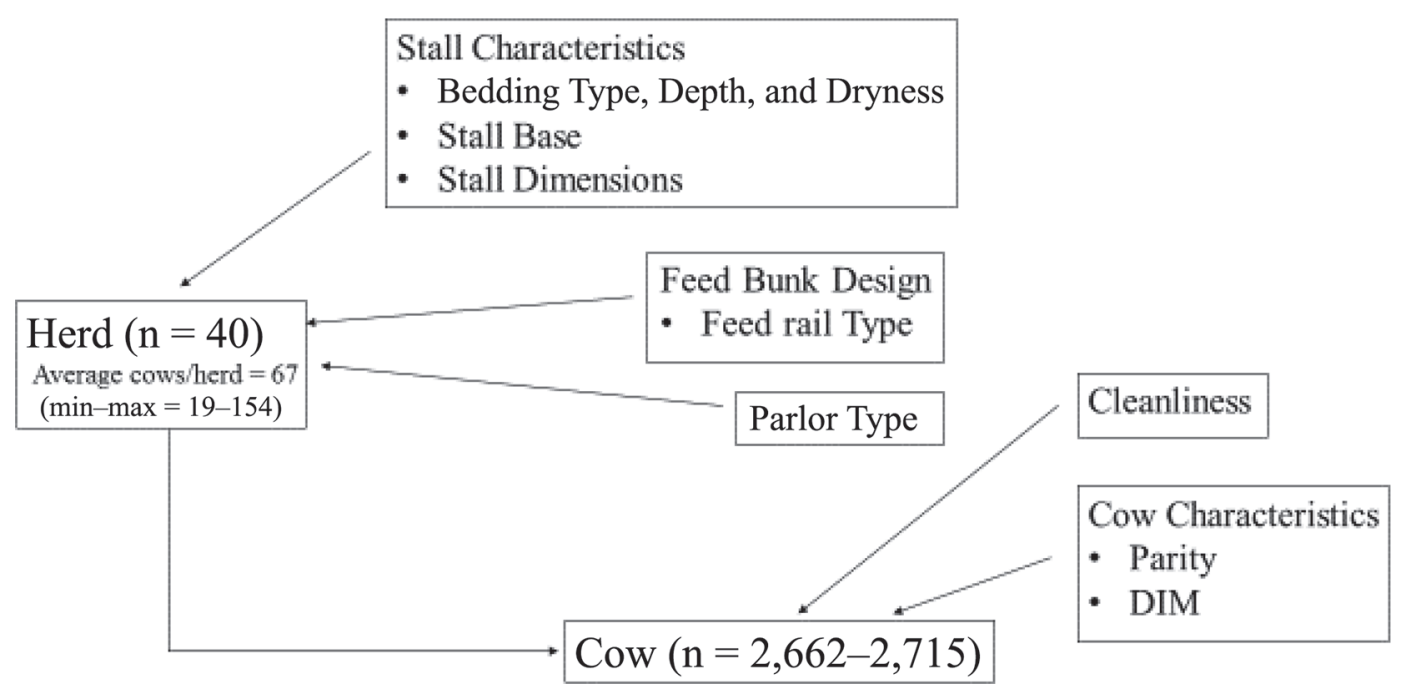

Figure 4. Hierarchical structure diagram illustrating the levels within the fixed-effects models for freestall facilities as well as the risk factors associated with these levels. $\min =$ minimum; $\max =$ maximum. 


\section{Prevalence of Hock, Knee, and Neck Skin Lesions in Freestalls}

The cow-level prevalence of hock lesions across the 40 freestall herds was $38.7 \%$ (95\% CI: 29.2-49.1). The within-herd prevalence ranged from 0 to $83.3 \%$ (Supplemental Figure S4; https://doi.org/10.3168/jds $.2018-15080)$. Of the 3,108 cows assessed for hock lesions, 40, 16, 42, and $2 \%$ had a maximum score of 0,1 , 2 , and 3, respectively. The cow-level prevalence of knee lesions across all herds was 13.6\% (95\% CI: 10.5-17.6), ranging from 0 to $60 \%$ within each herd (Supplemental Figure S5; https://doi.org/10.3168/jds.2018-15080). Of the 3,118 cows assessed for knee lesions, $73,11,16$, and $1 \%$ had a maximum score of $0,1,2$, and 3 , respectively. The cow-level prevalence of neck lesions was 1.0\% (95\% CI: $0.4-2.3)$. The within-herd prevalence ranged from 0 to $21.2 \%$ (Supplemental Figure S6; https://doi.org/10 $.3168 /$ jds.2018-15080). Of the 3,129 cows assessed for neck lesions, 92, 4, and $4 \%$ had a score of 0,1 , and 2 , respectively.

\section{Factors Associated with Hock, Knee, and Neck Skin Lesions in Tiestalls}

All of the factors that were unconditionally associated with each outcome of interest, as shown in Supplemental Tables S6 and S7 (https://doi.org/10.3168/jds .2018-15080), were used in the multivariable analysis because none were highly correlated. An outline of the hierarchical structure of the model, as well as the risk factors for all 3 outcomes, can be found in Figure 3. Risk factors that were significantly associated with hock lesions in tiestall-housed cows, as determined by multivariable analysis, are presented in Table 3. One of these factors was the type of bedding, where cows bedded with bedding material other than straw alone had 1.62 times the odds $(P=0.027)$ of hock lesions compared with those bedded with straw or hay alone. The proportion of random variation at the herd level explained by this model was $7 \%$. Factors significantly associated with knee lesions in the final multivariable model are presented in Table 4 . The proportion of ran-

Table 3. Final multilevel logistic regression model for hock lesions with cow- and herd-level factors in 33 tiestall farms in the Maritime Provinces of Canada $(\mathrm{n}=1,314)$

\begin{tabular}{|c|c|c|c|c|c|c|c|}
\hline Variable & Category & $\begin{array}{c}\text { Herds } \\
\text { or cows, } \\
\text { no. }(\%)\end{array}$ & Coefficient & SE & $\begin{array}{l}\text { Odds } \\
\text { ratio }\end{array}$ & $95 \% \mathrm{CI}$ & $\begin{array}{l}\text { Overall } \\
P \text {-value }\end{array}$ \\
\hline \multirow[t]{3}{*}{ Stall base } & Mattress & $6(18)$ & Referent & - & - & - & 0.012 \\
\hline & Concrete & $11(33)$ & -0.96 & 0.33 & 0.38 & $0.20-0.73$ & \\
\hline & Rubber mat & $16(49)$ & -0.11 & 0.27 & 0.90 & $0.53-1.51$ & \\
\hline \multirow[t]{2}{*}{ Bedding type } & Straw/hay & $19(58)$ & Referent & - & - & - & 0.027 \\
\hline & Other & $14(42)$ & 0.52 & 0.24 & 1.69 & $1.06-2.68$ & \\
\hline \multirow[t]{3}{*}{ Manger wall height $(\mathrm{cm})$} & $<10$ & $341(26)$ & -0.74 & 0.22 & 0.48 & $0.31-0.73$ & 0.002 \\
\hline & 10-19 & $652(50)$ & Referent & - & - & - & \\
\hline & $\geq 20$ & $321(24)$ & -0.35 & 0.23 & 0.70 & $0.45-1.09$ & \\
\hline \multirow[t]{3}{*}{ Chain length $(\mathrm{cm})$} & $\overline{<} 50$ & $191(15)$ & -0.58 & 0.24 & 0.56 & $0.35-0.89$ & 0.019 \\
\hline & $50-79$ & $847(64)$ & Referent & - & - & - & \\
\hline & $\geq 80$ & $276(21)$ & 0.27 & 0.20 & 1.31 & $0.88-1.96$ & \\
\hline \multirow[t]{4}{*}{ Stall length (cm) } & $<165$ & $176(13)$ & 0.86 & 0.26 & 2.36 & $1.41-3.95$ & 0.006 \\
\hline & $165-174$ & $558(42)$ & 0.09 & 0.17 & 1.09 & $0.77-1.53$ & \\
\hline & $175-184$ & $415(32)$ & Referent & - & - & - & \\
\hline & $\geq 185$ & $165(13)$ & 0.15 & 0.24 & 1.16 & $0.73-1.85$ & \\
\hline \multirow[t]{4}{*}{ Parity } & $\overline{1}$ & $441(33)$ & Referent & - & - & - & $<0.001$ \\
\hline & 2 & $351(27)$ & -0.72 & 0.16 & 0.49 & $0.35-0.67$ & \\
\hline & 3 & 218 (17) & -0.68 & 0.19 & 0.51 & $0.35-0.74$ & \\
\hline & $\geq 4$ & $304(23)$ & -0.34 & 0.17 & 0.71 & $0.51-1.00$ & \\
\hline \multirow[t]{4}{*}{ DIM } & $<100$ & $328(25)$ & Referent & - & - & - & $<0.001$ \\
\hline & $100-199$ & $414(31)$ & 0.65 & 0.17 & 1.93 & $1.38-2.70$ & \\
\hline & $200-299$ & $367(28)$ & 0.62 & 0.18 & 1.86 & $1.29-2.66$ & \\
\hline & $\geq 300$ & $205(16)$ & 0.75 & 0.22 & 2.11 & $1.38-3.23$ & \\
\hline \multirow[t]{2}{*}{ Flank cleanliness } & $\overline{C l e a n}$ & $1,281(97)$ & Referent & - & - & - & 0.004 \\
\hline & Dirty & $33(3)$ & -1.65 & 0.57 & 0.19 & $0.06-0.58$ & \\
\hline \multirow[t]{4}{*}{$\mathrm{BCS}$} & $\leq 2.5$ & $254(19)$ & Referent & - & - & - & 0.001 \\
\hline & 2.75 & $513(39)$ & -0.72 & 0.19 & 0.49 & $0.34-0.70$ & \\
\hline & 3 & $307(23)$ & -0.38 & 0.21 & 0.69 & $0.46-1.03$ & \\
\hline & $\geq 3.25$ & $240(18)$ & -0.54 & 0.23 & 0.58 & $0.37-0.91$ & \\
\hline Constant & & & -0.53 & 0.47 & & & \\
\hline Variance herd level & & & 0.26 & 0.12 & & & \\
\hline
\end{tabular}


Table 4. Final multilevel logistic regression model for knee lesions with cow- and herd-level factors in 33 tiestall farms in the Maritime Provinces of Canada $(\mathrm{n}=1,477)$

\begin{tabular}{|c|c|c|c|c|c|c|c|}
\hline Variable & Category & $\begin{array}{c}\text { Cows } \\
\text { no. }(\%)\end{array}$ & Coefficient & $\mathrm{SE}$ & $\begin{array}{l}\text { Odds } \\
\text { ratio }\end{array}$ & $95 \% \mathrm{CI}$ & $\begin{array}{l}\text { Overall } \\
P \text {-value }\end{array}$ \\
\hline Manger wall height $(\mathrm{cm})$ & $\begin{array}{l}<10 \\
10-19 \\
\geq 20\end{array}$ & $\begin{array}{l}389(26) \\
742(50) \\
346(24)\end{array}$ & $\begin{array}{c}-0.21 \\
\text { Referent } \\
-0.94\end{array}$ & $\begin{array}{l}0.24 \\
- \\
0.31\end{array}$ & $\begin{array}{l}0.81 \\
- \\
0.39\end{array}$ & $\begin{array}{c}0.51-1.30 \\
- \\
0.21-0.72\end{array}$ & 0.010 \\
\hline Chain length $(\mathrm{cm})$ & $\begin{array}{l}<50 \\
50-79 \\
>80\end{array}$ & $\begin{array}{l}208(14) \\
923(62) \\
346(23)\end{array}$ & $\begin{array}{c}-0.51 \\
\text { Referent } \\
0.36\end{array}$ & $\begin{array}{l}0.27 \\
- \\
0.22\end{array}$ & $\begin{array}{l}0.60 \\
1.45\end{array}$ & $\begin{array}{c}0.36-1.02 \\
- \\
0.95-2.21\end{array}$ & 0.026 \\
\hline Stall width $(\mathrm{cm})$ & $\begin{array}{l}<120 \\
120-124 \\
125-134 \\
>135\end{array}$ & $\begin{array}{l}248(17) \\
437(30) \\
288(19) \\
504(34)\end{array}$ & $\begin{array}{c}0.65 \\
-0.12 \\
\text { Referent } \\
-0.02\end{array}$ & $\begin{array}{l}0.29 \\
0.24 \\
- \\
0.25\end{array}$ & $\begin{array}{l}1.92 \\
0.89 \\
- \\
0.98\end{array}$ & $\begin{array}{c}1.10-3.38 \\
0.55-1.43 \\
- \\
0.60-1.59\end{array}$ & 0.014 \\
\hline Flank cleanliness & $\begin{array}{l}\text { Clean } \\
\text { Dirty }\end{array}$ & $\begin{array}{c}1,425(96) \\
52(4)\end{array}$ & $\begin{array}{c}\text { Referent } \\
0.73\end{array}$ & - & $-\overline{2.07}$ & $1.07-4.03$ & 0.032 \\
\hline $\begin{array}{l}\text { Constant } \\
\text { Variance herd level }\end{array}$ & & & $\begin{array}{r}-1.50 \\
0.70\end{array}$ & $\begin{array}{l}0.27 \\
0.25\end{array}$ & & & \\
\hline
\end{tabular}

dom variation at the herd level was $17 \%$ in this model. Finally, the factors that were significantly associated with neck lesions in the final multivariable model are presented in Table 5. The proportion of random variation at the herd level explained by this model was $33 \%$.

\section{Factors Associated with Hock, Knee, and Neck Skin Lesions in Freestalls}

All of the variables unconditionally associated with the outcome of interest, as shown in Supplemental Tables S8 and S9 (https://doi.org/10.3168/jds.2018 -15080), were used in the final analysis, as there were no highly correlated variables. The hierarchical structure of the models and their associated risk factors can be seen in Figure 4. The factors that were significantly associated with hock lesions in the final multivariable model are presented in Table 6. The proportion of random variation at the herd level explained by this model was $6 \%$. The factors significantly associated with knee lesions in the final multivariable model are presented in Table 7 . The proportion of random variation at the herd level explained by this model was $13 \%$. The factors associated with neck lesions in the final multivariable model are presented in Table 8 . The proportion of random variation at the herd level explained by this model was $38 \%$.

\section{DISCUSSION}

One limitation of this study was that enrollment in the study was voluntary. Therefore, the potential of selection bias exists. It is possible that herds with more lesions or poor management would not participate. Even

Table 5. Final multilevel logistic regression model for neck lesions with cow- and herd-level factors in 33 tiestall farms in the Maritime Provinces of Canada $(\mathrm{n}=1,360)$

\begin{tabular}{|c|c|c|c|c|c|c|c|}
\hline Variable & Category & $\begin{array}{c}\text { Cows, } \\
\text { no. }(\%)\end{array}$ & Coefficient & SE & $\begin{array}{l}\text { Odds } \\
\text { ratio }\end{array}$ & $95 \% \mathrm{CI}$ & $\begin{array}{l}\text { Overall } \\
P \text {-value }\end{array}$ \\
\hline \multirow[t]{3}{*}{ Manger wall height (cm) } & $<10$ & $362(27)$ & 0.88 & 0.37 & 2.41 & $1.16-4.99$ & 0.026 \\
\hline & 10-19 & $671(49)$ & Referent & - & - & - & \\
\hline & $\geq 20$ & $327(24)$ & 0.72 & 0.45 & 2.04 & $0.84-4.95$ & \\
\hline \multirow[t]{5}{*}{ Tie rail to curb distance $(\mathrm{cm})$} & $\overline{<} 180$ & $195(14)$ & 1.37 & 0.50 & 3.93 & $1.48-10.44$ & 0.003 \\
\hline & $180-189$ & $319(23)$ & 0.45 & 0.47 & 1.56 & $0.62-3.93$ & \\
\hline & 190-199 & $514(38)$ & Referent & - & - & - & \\
\hline & $200-209$ & $186(14)$ & 1.48 & 0.46 & 4.37 & $1.77-10.81$ & \\
\hline & $\geq 210$ & $146(11)$ & 0.38 & 0.52 & 1.46 & $0.53-4.03$ & \\
\hline \multirow[t]{4}{*}{ Parity } & $\overline{1}$ & $465(34)$ & Referent & - & - & - & 0.001 \\
\hline & 2 & $357(26)$ & 0.46 & 0.31 & 1.58 & $0.86-2.92$ & \\
\hline & 3 & $227(17)$ & 0.85 & 0.33 & 2.33 & $1.22-4.44$ & \\
\hline & $\geq 4$ & $311(23)$ & 1.16 & 0.31 & 3.19 & $1.75-5.82$ & \\
\hline \multirow[t]{4}{*}{ Cow height $(\mathrm{cm})$} & $<146$ & $284(21)$ & 0.44 & 0.37 & 1.55 & $0.76-3.18$ & 0.016 \\
\hline & $146-149$ & $373(27)$ & 0.90 & 0.29 & 2.45 & $1.37-4.36$ & \\
\hline & $150-152$ & $451(33)$ & Referent & - & - & - & \\
\hline & $\geq 153$ & $252(19)$ & 0.72 & 0.32 & 2.05 & $1.10-3.81$ & \\
\hline Constant & & & -5.17 & 0.53 & & & \\
\hline Variance herd level & & & 1.61 & 0.70 & & & \\
\hline
\end{tabular}


Table 6. Final multilevel logistic regression model for hock lesions with cow- and herd-level factors on 40 freestall farms in the Maritime Provinces $(\mathrm{n}=2,662)$

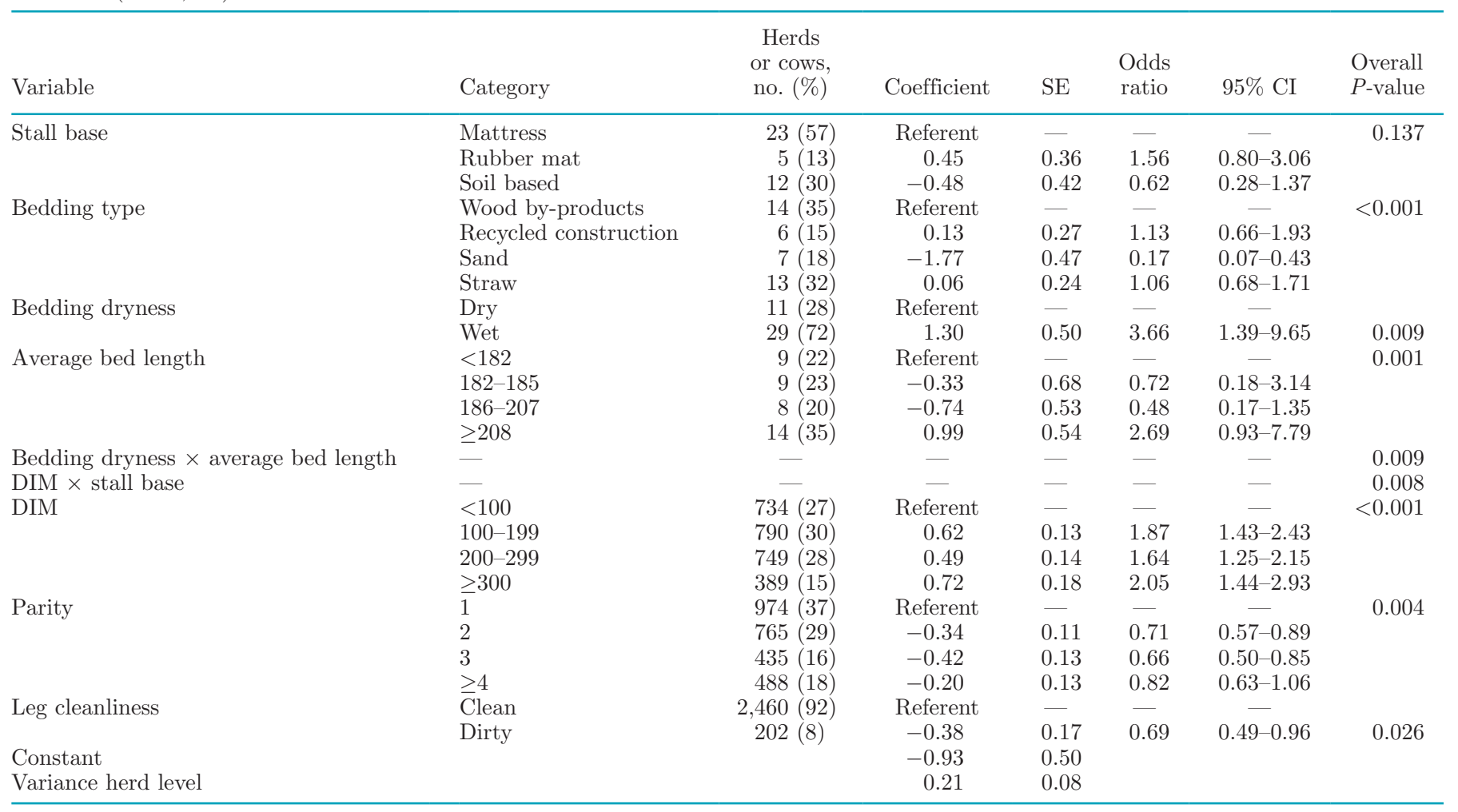

though the study population was not randomly selected from the population, we still found a wide variation between herds for the prevalence of skin lesions to the hock, knee, and neck, although the reported prevalence of lesions may be lower than if herds were randomly selected. The reported average Maritime herd size was 60 cows for tiestall herds and 120 cows for freestall herds. The reported average production across all Maritime herds was 10,187 kg/cow per year (CDIC, 2016). Due to the similarities between these average values and those found in our study population, we believe that they are representative of the farm demographics in this region.

As the management and environment of tiestall and freestall herds are very different, we looked at the risk factors for each facility separately. Despite these dif-

Table 7. Final multilevel logistic regression model for knee lesions with cow- and herd-level factors on 40 freestall farms in the Maritime Provinces $(\mathrm{n}=2,696)$

\begin{tabular}{|c|c|c|c|c|c|c|c|}
\hline Variable & Category & $\begin{array}{l}\text { Herds } \\
\text { or cows, } \\
\text { no. }(\%)\end{array}$ & Coefficient & SE & $\begin{array}{l}\text { Odds } \\
\text { ratio }\end{array}$ & $95 \%$ CI & $\begin{array}{l}\text { Overall } \\
P \text {-value }\end{array}$ \\
\hline \multirow[t]{3}{*}{ Parlor } & Herringbone & $20(50)$ & Referent & - & - & - & 0.014 \\
\hline & Automatic milking system & $5(13)$ & 0.10 & 0.39 & 1.10 & $0.51-2.37$ & \\
\hline & Other & $6(15)$ & 0.76 & 0.39 & 2.13 & $1.00-4.55$ & \\
\hline \multirow[t]{2}{*}{ Bedding type } & Wood by-product & $14(35)$ & Referent & - & - & - & 0.024 \\
\hline & Straw & $13(32)$ & 0.39 & 0.32 & 1.48 & $0.79-2.80$ & \\
\hline \multirow[t]{4}{*}{ Parity } & 1 & $988(37)$ & Referent & - & - & - & $<0.001$ \\
\hline & 2 & $771(29)$ & -0.17 & 0.14 & 0.84 & $0.64-1.11$ & \\
\hline & 3 & $442(16)$ & -0.20 & 0.17 & 0.82 & $0.58-1.14$ & \\
\hline & $\geq 4$ & $495(18)$ & 0.52 & 0.15 & 1.69 & $1.26-2.27$ & \\
\hline Constant & & & -2.25 & 0.27 & & & \\
\hline Variance herd level & & & 0.48 & 0.15 & & & \\
\hline
\end{tabular}


Table 8. Final multilevel logistic regression model for neck lesions with cow- and herd-level factors on 40 freestall farms in the Maritime Provinces $(\mathrm{n}=2,715)$

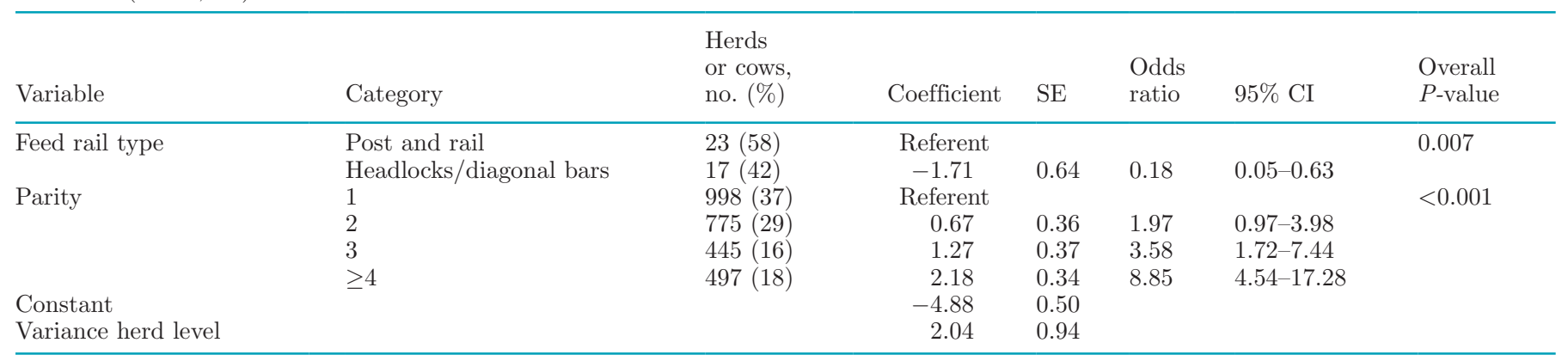

ferences, similar levels of lesions were found in the 2 systems. In both facility types, the prevalence of hock lesions was estimated to be $39 \%$. As expected, these results are comparable with previous Canadian studies using the same assessment protocols, which found that $47 \%$ of cows in freestalls (Zaffino Heyerhoff et al., 2014) and $51 \%$ in tiestalls (Nash et al., 2016) had hock lesions, although our results are slightly lower: the prevalence of knee lesions found in the current study was $14 \%$ in freestalls and $17 \%$ in tiestalls. Again, our results are comparable with but lower than the reported $24 \%$ in freestalls (Zaffino Heyerhoff et al., 2014) and 43\% in tiestalls (Nash et al., 2016) in similar Canadian assessments. The prevalence of neck lesions in this study was 1\% for freestalls and 5\% for tiestalls. These results are lower than reported previously for freestalls $(9 \%$; Zaffino Heyerhoff et al., 2014) and equivalent to those reported for tiestalls (4\%; Zurbrigg et al., 2005a). One explanation for the prevalence of lesions being lower in this study compared with earlier Canadian studies could be the implementation of animal care assessments through proAction (DFC, 2017). With the initiation of this program, producers have become more aware of these lesions because they are a part of the assessment. The majority of tiestall herds in the current study provided pasture access for their lactating cows, whereas the previous studies selected herds with minimal access to pasture. This is potentially another reason why we found a lower prevalence of lesions in tiestall herds, as grazing has been associated with minimizing hock and knee lesions (Haskell et al., 2006; Keil et al., 2006; Burow et al., 2013).

One risk factor that has been previously associated with hock lesions is whether the animal is obviously or severely lame (Rutherford et al., 2008; Zaffino Heyerhoff et al., 2014; Solano et al., 2015; Nash et al., 2016). As shown in the causal diagram in Figure 1, lameness and lesions to the hock and knee have a complex relationship with many common risk factors. It was for this reason that lameness was excluded from the analysis in the current study, allowing us to determine the direct association that these risk factors had with leg skin lesions.

Focusing on the environmental- and managementbased risk factors, in both tiestall and freestall facilities we found that the lying surface was associated with hock lesions. A common choice for the stall base is mattresses, likely because they provide additional cushioning over a concrete base, in theory making it more comfortable to lie down. However, the textile covering that is placed over this cushioning can cause friction and heat to the hock joint (Weary and Taszkun, 2000), increasing the risk of lesions. In agreement with previous studies, we found that compared with these mattresses, rubber mats were associated with more lesions in both facility types (Kielland et al., 2009; Nash et al., 2016). This could be because mattresses are more compressible compared with solid rubber mats (Fulwider and Palmer, 2004). In agreement with previous studies in freestall facilities, soil-based stalls were associated with lower odds of hock lesions compared with mattresses (Weary and Taszkun, 2000; Fulwider et al., 2007; Potterton et al., 2011; Zaffino Heyerhoff et al., 2014). A soil-based stall, such as sand, has the ability to conform to the shape of the cow when they lie down, reducing pressure and friction to the hock joint and reducing the likelihood of a lesion. There were no tiestall facilities with soil-based stalls in the study to make comparisons. We found that tiestalls with a concrete stall base had lower odds of hock lesions compared with mattresses (Zaffino Heyerhoff et al., 2014; Lim et al., 2015). Although we did not identify the amount of bedding material as a significant risk factor, this finding might have been due to provision of adequate bedding. Perhaps producers with concrete stalls were aware of their discomfort and compensated with additional bedding. It has also been found that cows housed on concrete stalls had shorter total lying times and fewer lying bouts than cows housed on mattress-based stalls (Haley et al., 2001), which would shorten their exposure time to the stall 


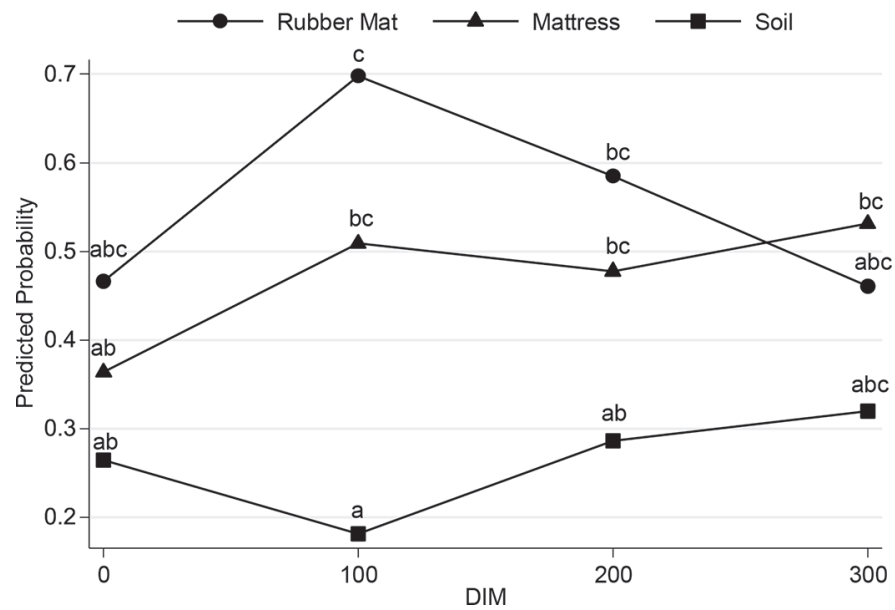

Figure 5. Plot of the predicted probability of hock lesions for the interaction between stall base and stage of lactation (DIM) in freestall facilities with all other variables being constant. Letters $(\mathrm{a}-\mathrm{c})$ above the points in the graph correspond to grouping after Bonferroni adjustment for multiple comparisons, where differences in letters correspond to significant differences.

base. Comparison of these results with freestalls was not possible because herds with concrete-based stalls were not included in our analysis.

Another factor to consider is the amount of time the cow has been exposed to the stall base. In this study, an interaction between the stall base and stage of lactation was found for freestall facilities, as shown in Figure 5. In agreement with previous studies, a trend that the odds of hock lesions tended to increase as DIM increased was observed (Kester et al., 2014; Zaffino Heyerhoff et al., 2014; Nash et al., 2016), specifically when cows were housed on rubber mats or mattresses. The probability of hock lesions was statistically higher in this housing environment compared with soil-based stalls when cows were 100 to 199 DIM. At this point in the production cycle, the probability of hock lesions tended to peak when cows were housed on rubber mats and mattresses, then decreased or plateaued. This trend was not seen in soil-based housing systems. During the remainder of the production cycle, there were no significant differences between stall types. These findings suggest that hock lesions are likely due to repeated trauma to the hock over the first 100 DIM. Once an animal develops a lesion, it is likely to persist throughout their lactation. Further longitudinal studies would be required to explore this relationship.

The type of bedding material that is used to cover the base of the stall was also associated with hock lesions in both facility types. In freestall facilities, deep-bedded sand stalls decreased the odds of lesions compared with other bedding products, such as shavings or sawdust, which can be more abrasive to the skin (Fulwider et al., 2007; Lombard et al., 2010; Andreasen and Forkman, 2012; Zaffino Heyerhoff et al., 2014). In tiestall facilities, we found that wood by-products, such as shavings or sawdust, or a combination of these products with straw increased the odds of lesions compared with straw alone. This agrees with previous work in both freestalls and tiestalls (Keil et al., 2006; Rutherford et al., 2008; Potterton et al., 2011), where straw bedding alone was found to provide a softer lying surface for the animals.

Another characteristic of the stall that was associated with hock lesions in both facility types was the length of the lying space (bed length). In tiestalls, cows in stalls that were shorter than recommended had higher odds of hock lesions than those in stalls of the recommended length, which is consistent with other work focusing on tethered animals (Keil et al., 2006). Longer stalls allow the animal to stand comfortably and raise or lower smoothly, although they can increase the risk of fecal and urine contamination (Bouffard et al., 2017). In freestall facilities, we found an interaction between the length of the stall and the dryness of the bedding. When the bedding material was dry, the lowest probability of lesions was seen when stall length was between 186 and $207 \mathrm{~cm}$; however, when the bedding material was wet, there were no significant differences between bed lengths, as shown in Figure 6 . We would expect that having wet bedding material would increase the risk of lesions because the exposure to urine can be very irritating and reduce the barrier effect of the skin, allowing it to become damaged more easily and become colonized by bacteria (Kester et al., 2014). It is important that the bedding material provided to the animals be kept dry to decrease the risk of hock lesions.

Two animal-based measurements that were associated with hock lesions that producers have the ability to influence are the cleanliness of the cow and BCS. In agreement with previous studies, odds of lesions were lower when the leg was dirty (Potterton et al., 2011). We found that the odds of hock lesions were lower when the flank region of tiestall cows and the lower leg of freestall cows was dirty. Although dirty animals are not desirable, the presence of dried, caked-on manure could act as a barrier for the skin, helping prevent ulceration of the hock. It is also possible that this finding could be a reflection of stall design and management. Supporting the results of other work, we found that thinner animals $(<2.75)$ had higher odds of lesions in tiestall facilities (Lim et al., 2015; Nash et al., 2016). Having more fat reserves would provide cushioning and additional protection over pressure points when lying down.

Focusing specifically on factors unique to tiestall facilities, we found that the length of the tether was 
associated with hock lesions. In contrast to previous work, we found that shorter chains decreased the odds of hock lesions (Zurbrigg et al., 2005b; Nash et al., 2016). It is uncertain why this contrasting result was found in this study. The manger wall is a stall design feature used to keep the cows from advancing in the stall and to separate the lying area from the feed bunk. Odds of lesions were higher when manger walls were built 10 to $20 \mathrm{~cm}$ in height compared with when they were built shorter or taller. This measurement could be related to the type of material used for the construction of the wall; however, this information was not collected during these assessments. Future work on stall design and construction material would be required to determine the relationship to lesions in tiestalls.

Focusing on lesions to the knee joint, no risk factors were common between tiestall and freestall facilities. The reason for this could be unmeasured animal factors, such as lying duration or lying bouts, or the differences in how these facilities are designed and managed (e.g., stall dimensions). Providing stalls that are designed to fit the animal is important, especially in tiestall housing, as the cows cannot choose which stall to lie in. In agreement with Nash et al. (2016), cows housed in narrow stalls had increased odds of knee lesions in tiestall facilities compared with those housed in wider stalls. When the cow does not fit in the stall properly, they are at a greater risk of coming into contact with design features of the stall when getting up and down. As with hock lesions, a manger wall height of 10 to $20 \mathrm{~cm}$ increased the odds of knee lesions compared with those that were higher and lower. Again, this could be influenced by the material used for the wall, and further investigation into the relationship of this stall design feature and lesions on the extremities would be required. As seen with the hock lesions in this study but in contrast to the work of Nash et al. (2016), shorter chains decreased the odds of knee lesions; the reason for this is not clear.

As with hock lesions, the cleanliness of the cow was associated with knee lesions in tiestall facilities. However, in contrast to the results for hock lesions in this study, cows with dirty flank regions had an increased risk of knee lesions. The reasons for a difference in the risk of hock and knee lesions based on the cleanliness of the cow were not readily apparent. This finding could be a reflection of the stall design or management.

When the cow lies down in the stall, the first thing her knee will come into contact with is the bedding. In contrast to hock lesions, we found that freestall facilities bedded with shavings or sawdust had lower odds of lesions compared with other types of bedding. Sandbedded stalls usually have a large concrete curb at the front of the stall that may not be sufficiently covered.

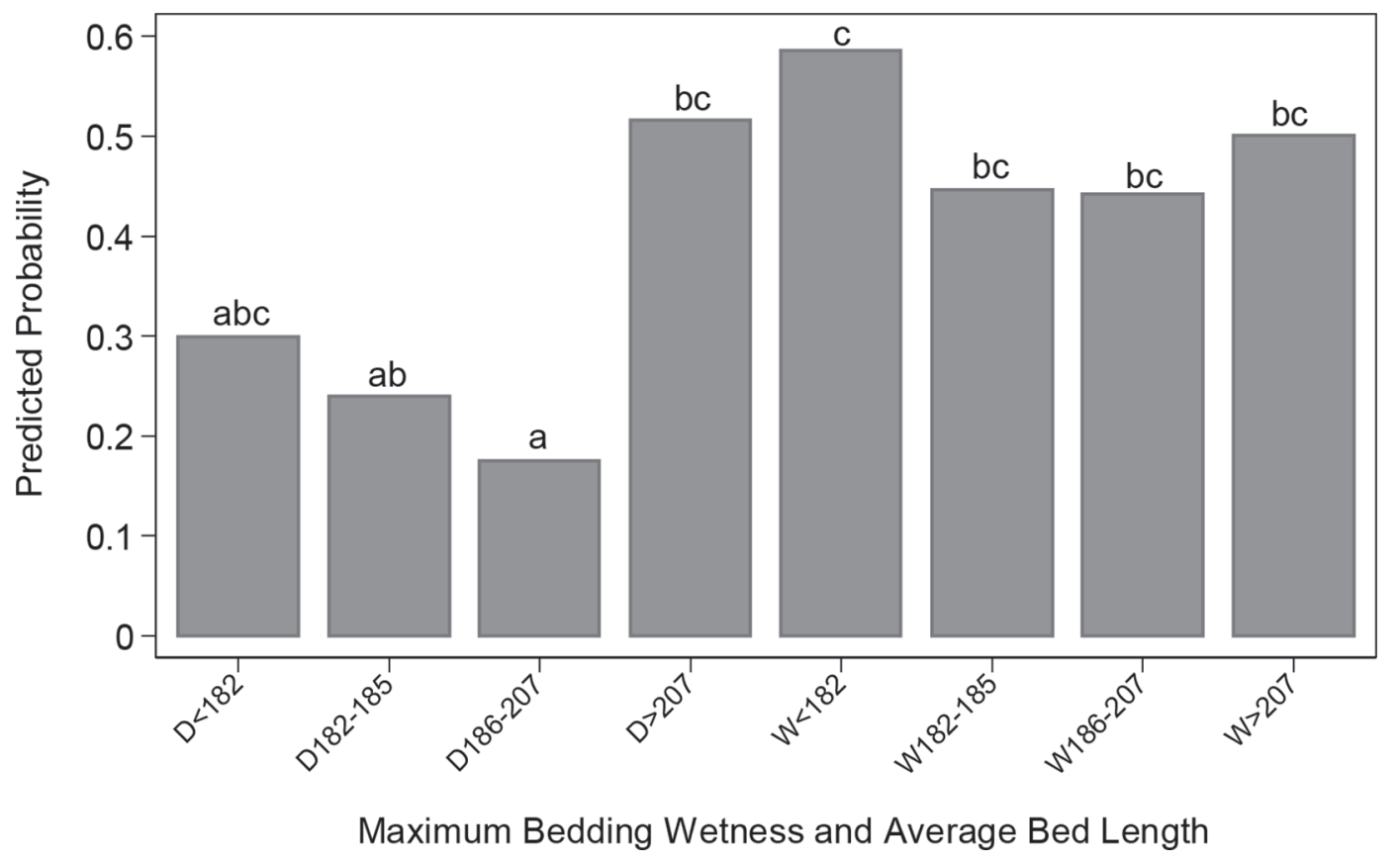

Figure 6. Predicted probability of hock lesions for the interaction term between bed length $(\mathrm{cm})$ and bedding wetness $(\mathrm{D}=\mathrm{dry}$; W $=$ wet $)$ in freestall facilities with all other variables being constant. Letters $(\mathrm{a}-\mathrm{c})$ above the bars correspond to grouping after Bonferroni adjustment for multiple comparisons, where differences in letters correspond to significant differences. 
These stalls generally do not have brisket locators, allowing the cows to lie farther forward in the stall and thus increasing the chance of their knees contacting the concrete curb. Another type of bedding that was used was recycled construction waste, which can contain very large and sharp pieces of wood that would be more traumatic to the knee joint compared with more finely processed by-products (shavings or sawdust). The type of bedding was not associated with knee lesions in tiestall facilities, perhaps due to the lack of variability in the types of bedding materials that were provided in these facilities.

An interesting finding in this study was the association between the type of milking parlor and knee lesions in freestall cattle. Compared with cows milked in herringbone parlors, cows milked in parallel parlors had lower odds of lesions and cows milked in other types of parlors had higher odds of lesions. Although focused on hock lesions only, a recent study in Sweden also found higher odds of lesions when herringbone parlors were used compared with tandem parlors. This was believed to be due to the flow of cows through the parlor, as tandem parlors allowed for cows to enter and exit individually (Ekman et al., 2018). Although no tandem parlors were present in the current study, the flow of cattle through the parlor could be an important factor. The specific design of how cows were released from the parlor was not recorded, but most parallel parlors release all of the cows at once rather than allowing them to leave single file, which may reduce crowding and pushing among cows as they are exiting. It is also possible that this finding is a reflection of unmeasured differences in facility design and management between these herds.

One of the main factors that influences whether a herd has neck lesions is how the neck rail or feed bunk is designed. By providing separation between cows at the feed bunk in the form of partitions or headlocks in freestalls, the number of displacements at the feed bunk is lowered (DeVries and von Keyserlingk, 2006; Huzzey et al., 2006). In tiestall facilities, the location of the tie rail is important to allow the animal to stand comfortably within the stall. We found an optimum distance of 190 to $200 \mathrm{~cm}$ from the tie rail to the rear curb, where the lowest odds of neck lesions was seen. A stall within this size frame accommodates an average-size cow comfortably and minimizes contact with the tie rail while eating and getting up and down. Another aspect of the stall design associated with neck lesions in tiestalls was manger wall height. When the height of the manger wall was between 10 and $20 \mathrm{~cm}$, odds of neck lesions were lower. The reasons for this finding are unknown and have not been noted previously. This finding could be associated with how the cow positions herself in the stall or how far she is required to reach for feed.

The parity of the cow was associated with all skin lesions; however, the pattern of the association differed between the locations. In agreement with previous work, older cows had higher odds of knee and neck lesions compared with first-lactation cows (Haskell et al., 2006; Zaffino Heyerhoff et al., 2014). In contrast to our findings for knee and neck lesions, we found that older cows had lower odds of hock lesions compared with first-lactation cows. This finding is the opposite of what other studies have found (Potterton et al., 2011; Zaffino Heyerhoff et al., 2014; Nash et al., 2016). This could be a reflection of the housing facility that the heifers are raised in. Heifers housed on straw yards (pack bedding) had a lower prevalence of hock lesions after calving than those housed on rubber mats (Livesey et al., 2002). In our study, heifers and dry cows were housed in pack-bedded facilities in $65 \%$ of the herds; therefore, it is likely that the first exposure to a stall occurred when they joined the lactating herd. They would not be accustomed to lying within a confined space, with potentially new bedding materials, and may not fit in the stall properly. This could affect how a heifer gets up and down in the stall, increasing her risk of developing a hock lesion.

In future work, assessing heifers and dry cows would be useful to determine whether some areas of management in these life stages are associated with lesions. This would help determine when and where animals are most likely to develop lesions. More detailed and precise methods for recording stall management factors, such as stall cleanliness and bedding depth, may have been beneficial in determining any potential associations between them and leg lesions. Additionally, looking at data from herds with activity monitoring would allow information about animal behavior to be captured and determine their associations with lesions (e.g., lying times).

\section{CONCLUSIONS}

This study found that the prevalence of hock, knee, and neck skin lesions can be high on dairy farms within the Maritime Provinces of Canada; however, many herds were able to achieve low levels of lesions. These results can be used as a benchmark to monitor changes over time and help motivate producers with higher levels of lesions to make improvements. Several risk factors were found to be related to the design of the barn and daily management, which could help producers make better decisions on how to manage their herd to reduce the prevalence of skin lesions. Although similar areas of 
risk were identified for tiestalls and freestalls, such as stall design and management, our study identified specific risk factors for each facility type. Having specific risk factors for each facility type can help better direct producers on where to implement changes. In general, providing soft and comfortable bedding in stalls with adequate space for cows to lie down and stand up with ease can reduce the odds of leg lesions. Designing tie rails and feed barriers to reduce contact with the neck and decrease displacements at the feed bunk can help reduce the number of neck lesions. The animal-based factors, such as cleanliness and BCS, are other areas where producers can focus on making changes to reduce the number of lesions as well as improving the overall welfare of their herd.

\section{ACKNOWLEDGMENTS}

This research was supported mainly by Agriculture and Agri-Food Canada (Ottawa, ON, Canada) and by additional contributions from Dairy Farmers of Canada (Ottawa, ON, Canada), the Canadian Dairy Network (Guelph, ON, Canada), and the Canadian Dairy Commission under the Agri-Science Clusters Initiative (Ottawa, ON, Canada). Per the research agreement, aside from providing financial support, the funders have no role in the design and conduct of the studies, data collection and analysis, or interpretation of the data. The researchers maintain independence in conducting their studies, own their data, and report the outcomes regardless of the results. The decision to publish the findings rests solely with the researchers. This research was also supported by the Sir James Dunn Animal Welfare Centre at the Atlantic Veterinary College (Charlottetown, PE, Canada). We thank the technicians and students from Maritime Quality Milk (Charlottetown, PE, Canada) for their work collecting the data and Valacta Inc. (Sainte-Anne-de-Bellevue, QC, Canada) for the use of their production records.

\section{REFERENCES}

Andreasen, S. N., and B. Forkman. 2012. The welfare of dairy cows is improved in relation to cleanliness and integument alterations on the hocks and lameness when sand is used as stall surface. J. Dairy Sci. 95:4961-4967.

Bouffard, V., A. M. de Passillé, J. Rushen, E. Vasseur, C. G. R. Nash, D. B. Haley, and D. Pellerin. 2017. Effect of following recommendations for tiestall configuration on neck and leg lesions, lameness, cleanliness, and lying time in dairy cows. J. Dairy Sci. 100:29352943.

Burow, E., P. T. Thomsen, T. Rousing, and J. T. Sørensen. 2013. Daily grazing time as a risk factor for alterations at the hock joint integument in dairy cows. Animal 7:160-166.

CDIC (Canadian Dairy Information Centre). 2016. Dairy facts and figures. Accessed Jan. 5, 2018. http://www.dairyinfo.gc.ca/index _e.php?s1=dff-fcil.
Chapinal, N., Y. Liang, D. M. Weary, Y. Wang, and M. A. von Keyserlingk. 2014. Risk factors for lameness and hock injuries in Holstein herds in China. J. Dairy Sci. 97:4309-4316.

DeVries, T. J., and M. A. G. von Keyserlingk. 2006. Feed stalls affect the social and feeding behaviour of lactating cows. J. Dairy Sci. 89:3522-3531.

DFC (Dairy Farmers of Canada). 2017. proAction. Accessed Jan. 15, 2018. https://www.dairyfarmers.ca/proaction/resources/animal -care.

Dohoo, I., W. Martin, and H. Stryhn. 2009. Veterinary Epidemiologic Research. 2nd ed. VER Inc., Charlottetown, PE, Canada.

Dolecheck, K., and J. Bewley. 2018. Animal board invited review: Dairy cow lameness expenditures, losses and total cost. Animal 12:1462-1474.

Ekman, L., A. K. Nyman, H. Landin, and K. Persson Waller. 2018. Hock lesions in dairy cows in free-stall herds: A cross-sectional study of prevalence and risk factors. Acta Vet. Scand. 60:47. https: //doi.org/10.1186/s13028-018-0401-9.

Elanco Animal Health. 1996. Body Condition Scoring. Bulletin AI 8478. Elanco Animal Health, Indianapolis, IN.

Fulwider, W. K., T. Grandin, D. J. Garrick, T. E. Engle, W. D. Lamm, N. L. Dalsted, and B. E. Rollin. 2007. Influence of free-stall base on tarsal joint lesions and hygiene in dairy cows. J. Dairy Sci. 90:3559-3566.

Fulwider, W. K., and R. W. Palmer. 2004. Use of impact testing to predict softness, cow preference, and hardening over time of stall bases. J. Dairy Sci. 87:3080-3088.

Gibbons, J., E. Vasseur, J. Rushen, and A. M. de Passillé. 2012. A training programme to ensure high repeatability of injury scoring of dairy cows. Anim. Welf. 21:379-388.

Haager, D. 2016. Validation of hock lesions as welfare indicator in dairy cows: A macroscopic, thermographic and histological study. MS Thesis. University of Natural Resources and Life Sciences, Vienna, Austria.

Haley, D. B., A. M. de Passillé, and J. Rushen. 2001. Assessing cow comfort: Effects of two floor types and two tie stall designs on the behaviour of lactating dairy cows. Appl. Anim. Behav. Sci. 71:105-117.

Haskell, M. J., L. J. Rennnie, V. A. Bowell, M. J. Bell, and A. B. Lawrence. 2006. Housing system, milk production, and zero-grazing effects on lameness and leg injury in dairy cows. J. Dairy Sci. 89:4259-4266.

Huzzey, J. M., T. J. DeVries, P. Valois, and M. A. G. von Keyserlingk. 2006. Stocking density and feed barrier design affect the feeding and social behaviour of dairy cattle. J. Dairy Sci. 89:126-133.

Keil, N. M., T. U. Wiederkehr, K. Friedli, and B. Wechsler. 2006. Effects of frequency and duration of outdoor exercise on the prevalence of hock lesions in tied Swiss dairy cows. Prev. Vet. Med. 74:142-153.

Kester, E., M. Holzhauer, and K. Frankena. 2014. A descriptive review of the prevalence and risk factors of hock lesions in dairy cows. Vet. J. 202:222-228.

Kielland, C., L. E. Ruud, A. J. Zanella, and O. Østerås. 2009. Prevalence and risk factors for skin lesions on legs of dairy cattle housed in freestalls in Norway. J. Dairy Sci. 92:5487-5496.

Lim, P. Y., J. N. Huxley, M. J. Green, A. R. Othman, S. L. Potterton, C. G. Brignell, and J. Kaler. 2015. Area of hock hair loss in dairy cows: Risk factors and correlation with a categorical scale. Vet. J. 203:205-210.

Livesey, C. T., C. Marsh, J. A. Metcalf, and R. A. Laven. 2002. Hock injuries in cattle kept in straw yards or cubicles with rubber mats or mattresses. Vet. Rec. 150:677-679.

Lombard, J. E., C. B. Tucker, M. A. von Keyserlingk, C. A. Kopral, and D. M. Weary. 2010. Associations between cow hygiene, hock injuries, and free stall usage on US dairy farms. J. Dairy Sci. 93:4668-4676.

Nash, C. G. R., D. F. Kelton, T. J. DeVries, E. Vasseur, J. Coe, J. C. Zaffino Heyerhoff, V. Bouffard, D. Pellerin, J. Rushen, A. M. de Passillé, and D. B. Haley. 2016. Prevalence of and risk factors for hock and knee injuries on dairy cows in tiestall housing in Canada. J. Dairy Sci. 99:6494-6506. 
Potterton, S. L., M. J. Green, J. Harris, K. M. Millar, H. R. Whay, and J. N. Huxley. 2011. Risk factors associated with hair loss, ulceration, and swelling at the hock in freestall-housed UK dairy herds. J. Dairy Sci. 94:2952-2963.

Rutherford, K. M. D., H. M. Langford, M. C. Jack, L. Sherwood, A. B. Lawrence, and M. J. Haskell. 2008. Hock injury prevalence and associated risk factors on organic and nonorganic dairy farms in the United Kingdom. J. Dairy Sci. 91:2265-2274.

Solano, L., H. W. Barkema, E. A. Pajor, S. Mason, S. J. LeBlanc, J. C. Zaffino Heyerhoff, C. G. Nash, D. B. Haley, E. Vasseur, D. Pellerin, J. Rushen, A. M. de Passillé, and K. Orsel. 2015. Prevalence of lameness and associated risk factors in Canadian Holstein-Friesian cows housed in freestall barns. J. Dairy Sci. 98:6978-6991.

Vasseur, E., J. Gibbons, J. Rushen, and A. M. de Passillé. 2013. Development and implementation of a training program to ensure high repeatability of body condition scoring of dairy cows. J. Dairy Sci. 96:4725-4737.

Vasseur, E., J. Gibbons, J. Rushen, D. Pellerin, E. Pajor, D. Lefebvre, and A. M. de Passillé. 2015. An assessment tool to help producers improve cow comfort on their farms. J. Dairy Sci. 98:698-708. von Keyserlingk, M. A. G., A. Barrientos, K. Ito, E. Galo, and D. M. Weary. 2012. Benchmarking cow comfort on North American freestall dairies: Lameness, leg injuries, lying time, facility design, and management for high-producing Holstein dairy cows. J. Dairy Sci. 95:7399-7408.

Weary, D. M., and I. Taszkun. 2000. Hock lesions and free-stall design. J. Dairy Sci. 83:697-702.

Zaffino Heyerhoff, J. C., S. J. LeBlanc, T. J. DeVries, C. G. R. Nash, J. Gibbons, K. Orsel, H. W. Barkema, L. Solano, J. Rushen, A. M. de Passillé, and D. B. Haley. 2014. Prevalence of and factors associated with hock, knee, and neck injuries on dairy cows in freestall housing in Canada. J. Dairy Sci. 97:173-184.

Zurbrigg, K., D. Kelton, N. Anderson, and S. Millman. 2005a. Stall dimensions and the prevalence of lameness, injury, and cleanliness on 317 tie-stall dairy farms in Ontario. Can. Vet. J. 46:902-909.

Zurbrigg, K., D. Kelton, N. Anderson, and S. Millman. 2005b. Tiestall design and its relationship to lameness, injury, and cleanliness on 317 Ontario dairy farms. J. Dairy Sci. 88:3201-3210. 